Jurnal Ilmu-Ilmu Peternakan 26 (1): 16 - 22

ISSN: 0852-3681

E-ISSN: 2443-0765

CFakultas Peternakan UB, http://jiip.ub.ac.id/

\title{
Kandungan kolesterol, High Density Lipoprotein (HDL) dan low density lipopro- tein (LDL) darah burung puyuh dengan pemberian aditif cair buah naga merah
}

\author{
Khabib Arrosichin, Vitus Dwi Yunianto dan Fajar Wahyono \\ Fakultas Peternakan dan Pertanian Universitas Diponegoro, Semarang \\ Kompl. drh. R. Soejono Koesoemowardojo-Tembalang, Semarang Kode Pos 50275 \\ Khabib.fpp@gmail.com
}

\begin{abstract}
The study aims to determine, assess and evaluate the content of cholesterol, high density lipoprotein (HDL) and Low Density Lipoprotein (LDL) blood quail which were treated with liquid additive red dragon fruit. Materials used in the study were 200 female quails aged 14 days with an average weight of $13.61 \pm 0.49 \mathrm{~g}$. Ration composed by metabolizable energy content of $\pm 3000 \mathrm{kcal} / \mathrm{kg}$ and $\pm 20 \%$ of crude protein. The study consisted of 4 treatments and 5 replications. The treatments were (T0: without addition of liquid red dragon fruit (control); T1: addition of $5 \mathrm{ml}$ liquid red dragon fruit twice a day; T2: addition of $5 \mathrm{ml}$ liquid red dragon fruit once a day and T3: addition of 5 $\mathrm{ml}$ liquid red dragon fruit once in every two days). Blood sampling was performed in EDTA tube at the end of the study. Analysis of samples was carried out in health laboratory Semarang. The results were analyzed using analysis of variance (ANOVA). The study showed that the addition of liquid red dragon fruit additive had no significant effect (P> 0.05) on cholesterol, HDL and LDL of quil's blood.
\end{abstract}

Keywords: Quail, cholesterol; HDL, LDL, and red dragon fruit

\section{PENDAHULUAN}

Produksi telur burung puyuh relatif lebih cepat dibandingkan dengan ayam petelur maupun dengan itik petelur. Namun kandungan lemak khususnya kolesterol pada telur burung puyuh cukup tinggi yaitu 16-17 $\mathrm{mg}$ /gram. Hal ini juga mencerminkan tingginya kandungan kolesterol dalam darah ternak (Rahmat dan Wiradimadja, 2011).

Usaha untuk menurunkan kandungan kolesterol dalam darah burung puyuh dapat dilakukan dengan memanipulasi pakan diantaranya dengan pemberian aditif yang diharapkan mampu mempengaruhi profil lemak darah (kandungan kolesterol, LDL dan HDL). Salah satu sumber bahan aditif berasal dari buah naga merah (Hylocereus polyrhizus).

Secara morfologi buah naga termasuk tanaman tidak lengkap karena tidak memiliki daun yang mana hanya memiliki akar, batang dan cabang, bunga, buah serta biji (Kristanto, 2009). Berbagai zat aktif antihiperlipidemia yang terkandung dalam buah naga diantaranya vitamin B3 (niasin), vitamin C (asam askorbat) dan asam palmitat diyakini dapat meningkatkan kadar HDL (High Density Lipoprotein) (Mahattanawee et al., 2006). Yusof, et al. (2012) menambahkan bahwa buah naga merah segar mengandung 540,27 $\mathrm{mg} / 100 \mathrm{~g}$ vitamin $\mathrm{C}$ yang berfungsi sebagai antioksidan untuk mencegah kerusakan HDL akibat peroksidase lipid, 
pembentukan radikal bebas serta meningkatkan sekresi asam empedu. Selain itu, vitamin $\mathrm{C}$ pada buah naga merah mampu manghambat pembentukan kolesterol melalui proses menghambat kinerja enzim HMG-KoA reduktase yang mengontrol jalur biosintesis kolesterol dalam hati dan menghambat pembentukan mevalonat sehingga pembentukan kolesterol dapat (Budiatmaja dan Noer, 2014). Oleh karena itu, penelitian ini bertujuan untuk melihat pengaruh pemberian aditif cair buah naga merah terhadap kandungan kolesterol, High Density Lipoprotein (HDL) dan low density lipoprotein (LDL) darah burung puyuh.

\section{MATERI DAN METODE}

\section{Materi}

Materi yang digunakan dalam penelitian adalah burung puyuh burung puyuh Japonica betina (Coturnix coturnix japonica) umur 14 hari sebanyak 200 ekor dengan bobot ratarata $13,61 \pm 0,49$ g. Burung puyuh ditempatkan pada kandang yang berukuran $90 \times 60 \times 30 \mathrm{~cm}^{3}$ yang terbuat dari kayu dengan alas kawat kasa sebanyak 20 petak. Masing- masing petak diisi 10 ekor burung puyuh. Ransum yang digunakan tersusun atas enam bahan pakan. Komposisi dan kandungan nutrisi ransum tersaji pada Tabel 1.

Tabel 1. Komposisi dan kandungan nutrisi ransum penelitian

\begin{tabular}{ll}
\hline Bahan pakan & Komposisi (\%) \\
\hline Jagung kuning & 48,00 \\
Konsentrat & 30,00 \\
Bekatul & 8,00 \\
Tepung ikan & 7,00 \\
Bungkil kedelai & 6,00 \\
Top mix & 1,00 \\
\hline Total & 100 \\
Kandungan nutrisi & \\
Energi metabolis (kkal/kg) & 3012 \\
Protein kasar(\%) & 19,76 \\
Lemak kasar (\%) & 2,00 \\
Serat kasar (\%) & 3,86 \\
Abu (\%) & 8,25 \\
Kadar kalsium (\%) & 0,65 \\
Kadar fosfor (\%) & 0,65 \\
\hline
\end{tabular}

Keterangan: Hasil analisis proksimat Laboratorium Balai Pengkajian Teknologi Pertanian (BPTP) Jawa Tengah, Ungaran (2015).

\section{Metode}

Metode yang digunakan dalam penelitian ini adalah metode percobaan lapang menggunakan Rancangan Acak Lengkap (RAL) dengan 4 perlakuan dan 5 kali ulangan. Data yang dihasilkan dianalisa menggunakan ANOVA. Apabila terdapat perbedaan perlakuan dilanjutkan dengan Uji Jarak Berganda
Duncan's. Perlakuan yang diberikan antara lain:

$$
\begin{aligned}
\mathrm{T} 0= & (\text { ransum }+ \text { tanpa penambahan } \\
& \text { aditif cair buah naga }), \\
\mathrm{T} 1= & (\text { ransum }+ \text { penambahan aditif cair } \\
& \text { buah naga } 2 \times \text { sehari }(10 \\
& \text { ml/ekor } 1 \text { hari })) \\
\mathrm{T} 2= & (\text { ransum }+ \text { penambahan aditif cair } \\
& \text { buah naga } 1 \times \text { sehari }(5 \mathrm{ml} / \mathrm{ekor} / 1
\end{aligned}
$$


hari)),

$\mathrm{T} 3=($ ransum + penambahan aditif cair buah naga dua hari $1 \mathrm{x}$ dalam 2 hari ( $5 \mathrm{ml} / \mathrm{ekor} / 2$ hari)).

Variabel yang diukur dalam penelitian ini antara lain konsumsi pakan, kandungan kolesterol, low density lipoprotein dan high density lipoprotein darah burung puyuh. Prosedur penelitian meliputi beberapa tahap kegiatan antara lain tahap persiapan, tahap perlakuan dan tahap pengumpulan data. Pengambilan darah burung puyuh dilakukan pada akhir penelitian tepatnya pada umur 84 hari. Sampel darah burung puyuh dianalisis di Balai Laboratorium Kesehatan Semarang Jawa Tengah. Metode yang digunakan dalam pengukuran kolesterol dan HDL darah adalah Cholesterol Oxidase-PAP (CHOD-PAP), sedangkan pengukuran LDL darah menggunakan direct method. Rumus perhitungan kolesterol darah sebagai berikut:

Cholesterol $(\mathrm{mg} / \mathrm{dl})=\frac{\text { Sample }}{\text { Std } / \text { Cal }} \times$ Conc. Std/Cal.

Rumus perhitungan HDL darah sebagai berikut:

HDL - Cholesterol $(\mathrm{mg} / \mathrm{dl})=\frac{\text { Sample }}{\text { Standard }} \times$ Conc. Standard

Rumus perhitungan LDL darah sebagai berikut:

LDL-Cholesterol $(\mathrm{mg} / \mathrm{dl})=\frac{\text { Sample }}{\text { Calibrator }} \times$ Conc. Calibrator

\section{HASIL DAN PEMBAHASAN}

Hasil penelitian menunjukkan bahwa pemberian aditif cair buah naga merah tidak berpengaruh nyata $(\mathrm{P}>0,05)$ terhadap kandungan kolesterol, LDL dan HDP darah burung puyuh seperti yang disajikan pada Tabel 2.

Tabel 2. Komposisi dan kandungan nutrisi ransum penelitian

\begin{tabular}{|c|c|c|c|}
\hline Perlakuan & Kandungan kolesterol & 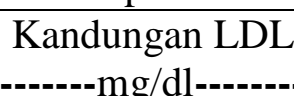 & Kandungan HDL \\
\hline T0 & 181,762 & 168,38 & 86,6 \\
\hline $\mathrm{T} 1$ & 206,954 & 195,00 & 80,2 \\
\hline $\mathrm{T} 2$ & 172,168 & 161,09 & 92,6 \\
\hline T3 & 159,180 & 146,07 & 99,8 \\
\hline
\end{tabular}

Keterangan: Hasil analisis Balai Laboratorium Kesehatan, Semarang (2015)

\section{Kolesterol darah}

Tabel 2 menunjukkan bahwa perlakuan pemberian adaitif cair buah naga merah (Hylocereus polyrhizus) pada T1 hingga T3 tidak menurunkan kandungan kolesterol darah secara signifikan $\quad(\mathrm{P}>0,05)$ dibandingakan dengan T0 (kontrol). Kandungan kolesterol darah burung puyuh menunjukkan hasil rata-rata yang normal. Hal ini sesuai dengan hasil penelitian Blaszczyk, et al. (2006) dimana kandungan kolesterol burung puyuh betina periode produksi berkisar antara $180-220 \mathrm{mg} / \mathrm{dl}$.
Pemberian aditif cair buah naga merah yang dibuat dengan penambahan air belum menunjukkan pengaruh yang nyata. Hal ini dapat disebabkan oleh jumlah pemberian yang relatif rendah (5$10 \mathrm{ml}$ ) sehingga zat aditif yang mampu memperbaiki kolesterol berupa vitamin B3 yang terkonsumsi juga relatif masih rendah yaitu $0,007-0,015 \mathrm{mg}$ sehingga belum optimal dalam menurunkan kandungan kolesterol dalam darah burung puyuh. Hasil penelitian Pereira (2010) menemukan bahwa jus buah naga merah mampu menurunkan kandungan kolesterol darah tikus putih secara 
signifikan dengan dosis 3,$6 ; 7,2$; dan $10,2 \mathrm{~g} / 200 \mathrm{~g} \mathrm{BB} /$ hari selama 21 hari. Kandungan vitamin B3 (niasin) diharapkan mampu menurunkan kandungan kolesterol darah melalui aliran asam lemak bebas jaringan adiposa yang mengurangi pembentukan lipoprotein yang membawa kolesterol (Indriasari, 2012).

\section{Low Density Lipoprotein (LDL) Darah}

Tabel 2 juga menunjukkan bahwa perlakuan pemberian adaitif cair buah naga merah (Hylocereus polyrhizus) tidak memberikan pengaruh terhadap kandungan LDL secara signifikan $(\mathrm{P}>0,05)$. Kandungan LDL darah burung puyuh pada penelitian ini tergolong tinggi apabila dibandingkan dengan hasil penelitian Karabulut, et al. (2006) yang berkisar antara 138-150 $\mathrm{mg} / \mathrm{dl}$. Sedangkan pada penelitian Fenita dan Suteky (2006) menunjukkan bahwa kandungan LDL darah burung puyuh periode bertelur adalah 90,45 $\mathrm{mg} / \mathrm{dl}$. LDL dalam darah mencerminkan kandungan kolesterol darah dimana sebanyak $90 \%$ kolesterol dalam bentuk LDL yang merupakan lipoproprotein terkecil dan berperan sebagai pengirim utama kolesterol dalam darah (Iryanti, 2005). Pemberian aditif cair buah naga merah dengan dosis rata-rata antara 3,5$10 \mathrm{ml} /$ hari belum mampu menurunkan tingginya kandungan LDL burung puyuh. Suryani (2015) meneliti bahwa pemberian jus buah naga merah (Hylocereus polyrhizus) pada beberapa dosis yaitu dosis rendah $(7,2 \mathrm{~g} / 200 \mathrm{~g}$ $\mathrm{BB} /$ hari), sedang (14,4 g/200 g BB/hari) maupun tinggi $(21,6 \mathrm{~g} / 200 \mathrm{~g} \mathrm{BB} / \mathrm{hari})$ selama 10 hari dapat menurunkan rerata kadar LDL tikus putih (Rattus norvegicus) secara signifikan. Kandungan vitamin $\mathrm{C}$ dan B3 diharapkan mampu mempengaruhi produksi VLDL sehingga penurunannya akan berpengaruh terhadap turunnya kandungan IDL dan LDL darah. Selain itu, vitamin $\mathrm{C}$ dalam buah naga merah membantu reaksi hidroksilasi dalam pembentukan asam empedu sehingga meningkatkan ekskresi kolesterol (Heryani, 2016).

\section{High Density Lipoprotein (HDL) Darah}

Hasil penelitian pada Tabel 2 menunjukkan bahwa perlakuan pemberian aditif cair buah naga merah (Hylocereus polyrhizus) pada T1 hingga T3 tidak meningkatkan kandungan HDL secara signifikan $(\mathrm{P}>0,05)$ dibandingkan dengan T0. Namun, kandungan HDL pada penelitian ini menunjukkkan nilai yang tinggi apabila dibandingkan dengan hasil penelitian Isnaeni, dkk (2010) dimana kandungan HDL darah burung puyuh $40,36 \mathrm{mg} / \mathrm{dl}$, sedangkan burung puyuh betina berumur 14 minggu memeiliki kandungan HDL darah sebanyak 18,75 mg/dl (Shenatmoko, et al. 2013).

Kandungan Vitamin B3 (niasin) buah naga merah diharapkan memberikan pengaruh terhadap sintesis pembentukan HDL darah. Hal ini dikarenakan niasin merupakan bagia dari B-kompleks yang berperan sebagai koenzim NAD (nicotin amide-adenin dinukleotida) dan NADP (nicotin amideadenin dinukleotid fosfat) yang sangat penting dalam reaksi oksidasi dan reduksi. Hal ini sesuai dengan hasil penelitian Fenita dan Suteky (2006) yang menyatakan bahwa pemberian niasin dalam dosis 0,2-1 $\mathrm{g} / \mathrm{kg}$ ransum dapat memberikan pengaruh terhadap peningkatan kandungan HDL darah burung puyuh dibandingkan perlakuan kontrol. Kadar HDL kolesterol akan meningkat karena terjadi peningkatan apolipoprotein A-1 yang dapat memacu sintesis HDL kolesterol. 


\section{KESIMPULAN}

Pemberian aditif cair buah naga merah (Hylocereus polyrhizus) sebanyak (5-10 ml/ekor) dengan frekuensi pemberian yang berbeda (satu kali sehari, dua kali sehari dan dua hari sekali) belum dapat menurunkan kandungan kolesterol dan Low Density Lipoprotein (LDL) dan belum mampu meningkatkan kandungan High Density Lipoprotein (LDL) burung puyuh betina fase produksi (layer).

\section{DAFTAR PUSTAKA}

Blaszczyk, B. T.U, Zofia. Darius, G. Tomasz, S. Danuta, S. Krystyna, R, dan Joanna, J. 2006. Changes in the blood plasma testosterone and cholesterol concentrations during sexual maturation of Pharaoh quails. Animal Science Papers and Reports. 24 (3): 259266.

Budiatmaja, A. C. dan E. R, Noer. 2010. Pengaruh pemberian jus buah naga merah (Hylrocereus polyrhizus) terhadap kadar kolesterol total pria hiperkolesterolemia. Journal of Nutrition College. 3(4): 655-664.

Fenita, Y. dan Suteky, T. 2006. Pengaruh pemberian niasin terhadap kandungan kolesterol telur dan perlemakan serum darah puyuh. Jurnal Sains Indonesia. 1(2):4548.

Heryani, R. 2016. Pengaruh ekstrak buah naga merah terhadap profil lipid darah tikus putih hiperlipidemia. Jurnal Ilmiah Medical. 5(1):1-9.

Indriasari. 2012. Ekstrak ethanol buah naga merah (Hylocereus polyrhizus) memperbaiki profil lipid tikus wistar jantan (Rattus norvegicus) dislipidemia. Tesis. Universitas Uduyana. Denpasar.

Iryanti, N. Tri, Y. Zuprizal dan Sunarjo, K. 2005. Pengaruh penggunaan asam lemak rantai panjang dalam pakan terhadap penampilan dan profil lemak darah serta gambaran ovarium ayam kampung betina. Buletin Peternakan 29(4): 177 - 184.

Isnaeni, W. Fitriyah, A dan Setiati, N. 2010. Studi penggunaan prekursor hormon steroid dalam pakan terhadap kualitas reproduksi burung puyuh jantan (Coturnix Coturnix Japonica). Jurnal Sains dan Teknologi. 8(2): 1-10.

Karabulut, K. Eren, M. B. Uyanik. Kocaodlu. G. 2006. The Effect of dietary baron supplementation on perfomence, carcass and serum lipid in Japanese quails. Journal of Animal and Veterinery Advances. 5(12): 1105-1108.

Kristanto, D. 2009. Buah naga pembudidayaan di pot dan di kebun. Penebar Swadaya. Jakarta.

Mahattanawee, K. J. A, Manthey. Luzio, G. S. T, Talcott. Goodner, K dan E. A, Baldwin. 2006. Total antioxidant activity and fiber contant of select florida-grown tropical fruit. Journal of Agricultural and Food Chemistry 5(54): 7355-7363.

Pareira, F. M. M. 2010. Pengaruh jus buah naga putih terhadap kadar kolesterol total tikus putih. Tesis. Fakultas Kedokteran. Universitas Sebelas Maret. Surakarta.

Rahmat, D. dan Wiradimadja, R. 2011. Pendugaan kadar kolesterol daging dan telur berdasarkan kolesterol darah pada puyuh Jepang. Jurnal Ilmu Ternak. 11(1): 35-38.

Shenatmoko, A. D. Aris, K. Gebby, C. V. G. Adi, R. Rysca, I dan Ratih, D. 2013. Pengaruh suplementasi betain terhadap beberapa 
parameter lipida dan protein darah pada puyuh. Jurnal Sains Peternakan.11(1):14-18.

Suryani, I. 2015. Pengaruh pemberian jus buah naga merah (Hylocereus polyrhizus) terhadap profil lipid tikus putih (Rattus Norvegicus) jantan model hiperlipidemia. Tesis. Universitas Sebelas Maret.
Surakarta.

Yusof, R. M. Norhayati dan Marhazlina.

A. K. M, Rohin. 2012. Effects of red pitaya fruit (Hylocereus polyrhizus) consumption on blood glucose level and lipid profile in type 2 diabetic subjects: Journal Borneo Science. 31(2):113-128 